\title{
Study of the mechanisms of antioxidative action of different antioxidants
}

\author{
Z. Marković1,2 \\ ${ }^{1}$ Department of Chemical-Technological Sciences, State University of Novi Pazar, Vuka \\ Karadžića bb, 36300 Novi Pazar, Republic of Serbia. \\ ${ }^{2}$ Bioengineering Research and Development Centre, 6 Prvoslava Stojanovića Street, 34000 \\ Kragujevac, Republic of Serbia. \\ e-mail: zmarkovic@np.ac.rs
}

\begin{abstract}
The reaction mechanisms by which antioxidants can exert their activity are: hydrogen atom transfer (HAT), proton coupled electron transfer (PCET), sequential proton loss electron transfer (SPLET), single electron transfer - proton transfer (SET-PT), radical adduct formation, and sequential proton loss hydrogen atom transfer. The antioxidative activity of different compounds (flavones, flavonols, and Schiff basis) was investigated by the trolox equivalent antioxidative capacity and electron paramagnetic resonance methods. The mechanisms of the antioxidative action (HAT, PCET, SPLET, and SET-PT) were investigated by using the thermodynamic parameters: bond dissociation enthalpy, ionization potential, proton dissociation enthalpy, proton affinity, and electron-transfer enthalpy. The influence of different radicals was investigated using appropriate isodesmic reactions. The mechanistic approach to the investigation of the influence of different radicals to the HAT mechanism, and the second step of the SET-PT mechanism) was applied. These investigations contribute to the elucidation and understanding of complex processes involved in the antioxidative action.
\end{abstract}

Keywords: DFT, antioxidants, HAT, PCET, SPLET

\section{Introduction}

Oxidative stress is a state of the cell in which the concentration of the reactive radical species exceeds the capacity of the endogenous antioxidative protection system (Barnham Et al. 2004; Sayre et al. 2008). The increased level of the oxidative stress may be one of the factors involved in the emergence of a large number of acute and chronic diseases. The reactive free radical species, in particular oxygen-centered radicals (ROS), may be responsible for the oxidative degradation of the vital biomolecules, lipids, proteins, nucleic acids (Barber et al. 2004; Ames et al. 1993). The oxidative degradation of biomolecules can accumulate for years, which contributes to aging and an increased risk for certain neurodegenerative diseases such as amyotrophic lateral sclerosis (ALS), Alzheimer's disease (AD) and Parkinson's disease (PD) (Barnham et al. 2004; Ames et al. 1993). Modern studies on the role of the oxidative stress in neurodegenerative diseases suggest that antioxidants can potentially be used for therapeutic purposes (Lleó et al. 2006; Mossmann et al. 2004; Troadec et al. 2001). 
The flavonoids are aromatic secondary plant metabolites, which belong to the class of plant polyphenols. Because of the remarkable array of biological and pharmacological activities these molecules are increasingly used as antioxidant, inhibiting, antiviral and antimicrobial agents which also exhibit vascular, anti-inflammatory and antiallergic activity. Phenolic acids are known antioxidants not only because of their ability to donate a hydrogen atom or an electron but also because of their stable intermediate radicals which prevent the oxidation of the various components of cereals, particularly fatty acids and oils. The antioxidant activity of phenolic acids is closely associated with the structure, the type, number and position of substituents on the aromatic rings as well as the structure of the side chains. Phenolic acids have different functions in plants including the assimilation of nutrients, protein synthesis, enzyme activity and photosynthesis.

Thione-substituted 1,2,4-triazoles represent an important class of heterocycles which are, owing to their numerous features, widely applied in various fields of medicinal and industrial chemistry. A large number of these derivatives exhibit diverse biological properties including anticonvulsant (Plech et al. 2014), antidepressant, (Kane et al. 1988) anti-inflammatory (Palaska et al. 2002), antibacterial, (Ezabadi et al. 2008) antifungal (Parker et al. 2011) and anticancer activity (Mavrova et al. 2009). The antioxidant activity of 1,2,4-triazole-3-thione (thiol) compounds has attracted much attention in relation to their radical-scavenging potential. In the context of the potential industrial applications, several 1,2,4-triazole-3-thiones have shown corrosion inhibition of copper and mild steel in chloride media and acidic solutions (Khiati et al. 2011; Kumara et al. 2012).

Antitumor, antiviral, antifungal and antibacterial activities of Schiff bases (RadeckaParyzek et al. 2007) have found application in medicine and pharmacy. Due to their biological properties, these compounds are used as basic materials for synthesis of antibiotics, antiallergics, antitumors and antifungal drugs (Lozier et al. 1975; Hodnett and Dunn 1970). It has also been reported that Schiff bases of salicylaldehydes have influence in plant growth (Alt 1981), and show some antimicrobial (Hamada et al. 1981) and antimycotic activity (Ismail 1986). These compounds are active against a wide range of organisms such as: Candida albicans, Escherichia coli, Staphylococcus aureus, Bacillus polymyxa, Trichophyton gypseum, Mycobacterium, Erysiphe graminis, and Plasmopara viticola (1). They also have the ability to rebuild hemoglobin, red blood and white blood cells (Ozaslan et al. 2011). Schiff bases also proved to be useful in treatment of AIDS and diabetes (Taha et al. 2013; Khan et al. 2013). Also, it was shown that some phenolic Schiff bases act as effective antioxidants and potential drugs that can prevent disease caused by free radical damage (Anuoar et al.2013; Taha et al. 2013; Khan et al. 2013; Khan et al. 2012; Chenga et al. 2011).

The antiradical activity mechanisms of the selected molecules and the stability of their readicals were examined using theoretical methods. Special attention was devoted to examination of the single electron HAT, PCET, SET-PT and SPLET mechanisms. The impact of the structure (number and position of $\mathrm{OH}$ groups), polarity of the solvents and the type of radicals were examined. Quantum mechanical calculation were included in silico approach. The conformational searches, optimization of the most stable structures and calculation of frequencies were carried out by using DFT method. The geometries of all compounds, including neutral molecules, radicals, anions, radical-anions and cations were fully optimized using M05-2X, M06-2X, and B3LYP functionals and 6-311 ++ G (d, p) base set in conjunction with the SMD and CPCM solvation models. Thermodynamically favorable mechanisms of the action of all the investigated molecules were quantitatively expressed through physicochemical descriptors such as BDE (bond dissociation enthalpy), IP (ionization potential), PDE (proton dissociation enthalpy), PA (proton affinity) and ETE (electron transfer enthalpy). The transition state theory was applied for the study of the reaction mechanisms (manly HAT and PCET), to 
describing the geometry of the corresponding transitional states, and calculating the reaction rate constants $(k)$.

\section{The antioxidant mechanisms}

The reactions of governing the antioxidant activity of different chemical compounds take place in highly complex environments. The complexity of the environment stems from a number of different radicals and antioxidants' reactive species, which are present in biological media. All of these species can be involved in chemical reaction related to the antioxidant activity. The importance of these compounds is related to both their concentrations and reactivity. On the other hand, the polarity of the environment and the $\mathrm{pH}$ value play an important role in these reactions. In this regard, different radicals can react via different mechanisms in different media. Therefore it becomes evident that elucidating the main reaction mechanisms involved in the antioxidant activities of chemical compounds may be a challenge. For these reasons some of the most important reaction mechanisms involved in antioxidant protection, from both experimental and theoretical approaches, are investigated in many cases. In this paper, some theoretical results will be presented in the case of different chemical compounds.

The antiradical properties of different natural and synthetic antioxidants (A-OH) are based on their ability to donate hydrogen atom to a free radical. In these reactions a newly formed radical, which is more stable and less reactive than the previous one, is generated. There are several mechanisms of the antioxidant actions of free radicals: hydrogen atom transfer (HAT), proton coupled electron Transfer (PCET), single electron transfer followed by proton transfer (SET-PT), sequential proton loss electron transfer (SPLET), radical adduct formation (RAF), and sequential proton loss hydrogen atom transfer (SPLHAT) (Klein et al. 2007; Litwinienko and Ingold 2007; Galano 2015; Galano et al. 2016; Mazzone et al. 2016).

\subsection{HAT and PCET mechanisms}

It is well known that identity reactions ( $\mathrm{RXH}+\mathrm{X}^{\cdot} \rightarrow \mathrm{RX}^{\bullet}+\mathrm{XH}$ ) involving HAT mechanism between two oxygen atoms have much lower activation energies and higher rate constants than HAT mechanism between two carbon atoms (Min et al. 2002). Mayer et al. (Rose et al. 1993) provided simple explanation for these differences. On the basis of DFT calculations they found that the transition states for for the $\mathrm{PhO}^{*}+\mathrm{PhOH}$ and $\mathrm{PhCH}_{2}{ }^{\circ}+\mathrm{PhCH}_{3}$ have quite different structures (Figure 1). In the reaction A, HAT involves transfer of a proton with one of its bonding electrons. However, in the reaction B between phenoxyl radical and phenol, a pretransition state complex is formed between the $\mathrm{OH}$ and a lone pair on $\mathrm{O}^{*}$. It means that proton is transferred from phenol to the radical's lone pair. On the other hand, electron moves from the $2 p$ lone pair of the phenol to the singly occupied molecular orbital (SOMO) of phenoxyl radical. The authors find that the energy barrier is lower and narrower for reaction phenoxyl radical/ phenol compared to benzyl/toluene reaction. 

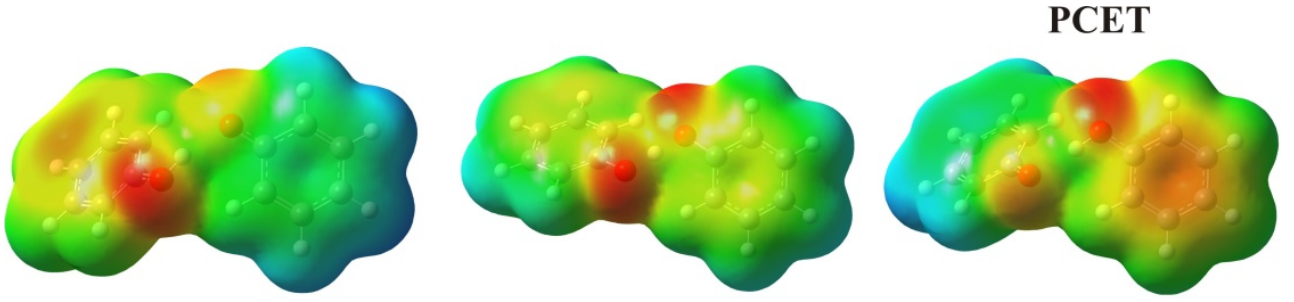

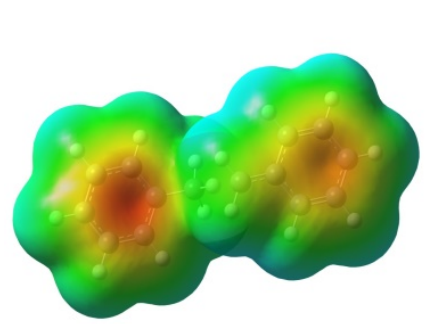

reactant

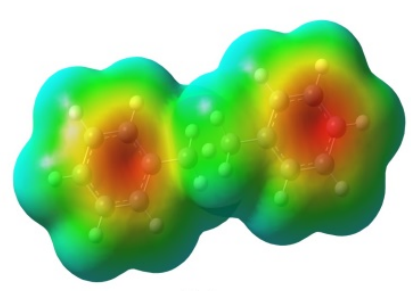

transition state

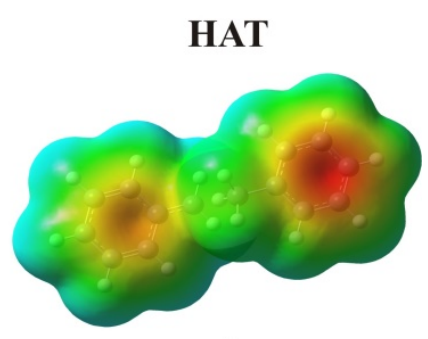

product

Fig. 1. Electrostatic potential maps for HAT (benzyl/toluene) and PCET (phenoxyl/phenol) mechanisms

In the HAT and PCET mechanisms, a hydrogen atom is transferred to a free radical:

$$
\mathrm{A}-\mathrm{OH} \rightarrow \mathrm{A}-\mathrm{O}^{\bullet}+\mathrm{H}^{\bullet}
$$

this mechanism is characterized by the homolytic bond dissociation enthalpy (BDE) of $\mathrm{OH}$ groups. This thermodynamical value can be calculated using the following equation:

$$
\mathrm{BDE}=H\left(\mathrm{~A}-\mathrm{O}^{\bullet}\right)+H\left(\mathrm{H}^{\bullet}\right)-\mathrm{H}(\mathrm{A}-\mathrm{OH})
$$

$H(\mathrm{~A}-\mathrm{OH}), H(\mathrm{~A}-\mathrm{OH})$, and $H\left(\mathrm{H}^{\bullet}\right)$ are enthalpies of the parent molecule, corresponding radical, and hydrogen atom, respectively. A higher BDE value is attributed to a lower ability for donating an $\mathrm{H}$ atom.

\subsection{Radical Adduct Formation (RAF)}

The RAF mechanism can be schematically represented as:

$$
\mathrm{A}-\mathrm{OH}+\cdot{ }^{\cdot} \mathrm{R} \rightarrow[\mathrm{A}-\mathrm{OH}-\mathrm{R}]^{\cdot}
$$

$\mathrm{A}-\mathrm{OH},{ }^{\circ} \mathrm{R}$, and $[\mathrm{A}-\mathrm{OH}-\mathrm{R}]^{\bullet}$ represent an antioxidant, free radical, and the obtained free-radical adduct, respectively. This mechanism represents a reaction between antioxidant and the free radical. In contrast to the HAT and PCET mechanisms, the antioxidant does not provide its hydrogen atom, but forms the radical adduct with the free-radical. This mechanism depends on the structure of the investigated antioxidant and the free radical. If the investigated antioxidant has multiple bonds, then the RAF is possible reaction path. In addition, the properties of the free radical play an important role, the electrophilic free radicals have the greatest potential for participation in this type of reactions. Generally speaking, the reaction centre of the investigated antioxidant should be easily accessible, a free radical should be a small or medium sized to avoid potential steric hindrance. The RAF is the most likely mechanism for the free radical scavenging of hydroxyl radical with: gentisic acid (Joshi et al. 2012) caffeine (León-Carmona et al. 2011), melatonin (Galano et al. 2011)], and its metabolites (Galano et al. 2013; Galano et al. 2014), hydroxybenzyl alcohols (Dhiman et al. 2009) and carnosine (Tamb et al. 1999). 


\subsection{SET-PT mechanism}

This mechanism is also known as Sequential Electron Proton Transfer (SEPT). In the first step of the SET-PT mechanism a phenolic compound loses an electron, and yields the corresponding radical cation $\mathrm{Ph}-\mathrm{OH}^{\bullet+}$.

$$
\mathrm{A}-\mathrm{OH} \rightarrow \mathrm{A}-\mathrm{OH}^{\bullet+}+\mathrm{e}^{-}
$$
follows:

This first step is characterized by the ionization potential (IP) which can be calculated as

$$
\mathrm{IP}=H\left(\mathrm{~A}-\mathrm{OH}^{\bullet+}\right)+H\left(\mathrm{e}^{-}\right)-H(\mathrm{~A}-\mathrm{OH})
$$

$H\left(\mathrm{~A}-\mathrm{OH}^{\bullet+}\right)$ and $H\left(\mathrm{e}^{-}\right)$are the enthalpies of the radical cation and electron, respectively.

The second step of this mechanism is deprotonation of $\mathrm{A}-\mathrm{OH}^{\bullet+}$ :

$$
\mathrm{A}-\mathrm{OH}^{\bullet+} \rightarrow \mathrm{A}-\mathrm{O}^{\bullet}+\mathrm{H}^{+}
$$

This reaction step is characterized by proton dissociation enthalpy (PDE) of $\mathrm{O}-\mathrm{H}$ bonds. PDE can be calculated using the following equation:

$$
\mathrm{PDE}=H\left(\mathrm{Ph}-\mathrm{O}^{\bullet}\right)+H\left(\mathrm{H}^{+}\right)-H\left(\mathrm{Ph}-\mathrm{OH}^{\bullet+}\right)
$$

where $H\left(\mathrm{H}^{+}\right)$is the enthalpy of proton.

The solvent plays an important role in this mechanism. In the first step of this reaction radical cation is formed. Therefore polar solvent is necessary for this mechanism to stabilize the resulting intermediate. Moreover, polar solvent should be also protic due to the nature of the second step of this mechanism.

This mechanism is much less present in comparison to HAT and PCET mechanisms because the first step which is very slow. On the other hand, once formed the radical cation easily losts proton in the second step of this mechanism, for example in the case of baicalein (Marković et al. 2012) and quercetin (Marković et al. 2013). On the other hand, SET-PT mechanism plays an important role in the oxidative damage of biomolecules by highly reactive radicals such as hydroxyl radical. For instance, the SET-PT mechanism is the main reaction path for reaction of the guanosine and hydroxyl radical (Galano et al. 2009).

\subsection{Sequential Proton Loss Electron Transfer (SPLET)}

The SPLET mechanism is two steps mechanism, proposed by Ingold and Litwinienko (Litwinienko and Ingold 2003; Litwinienko and Ingold 2004; Litwinienko and Ingold 2005; Litwinienko and Ingold 2007). The first step in the SPLET mechanism Litwinienko and Ingold (2007), Foti et al. (2004) is deprotonation of the corresponding antioxidant, followed by the antioxidant anion $\mathrm{A}^{-} \mathrm{O}^{-}$formation:

$$
\mathrm{A}-\mathrm{OH} \rightarrow \mathrm{A}-\mathrm{O}^{-}+\mathrm{H}^{+}
$$

This step is described by proton affinity (PA) of the antioxidant anion. PA can be calculated by means of the following equation:

$$
\mathrm{PA}=H\left(\mathrm{~A}-\mathrm{O}^{-}\right)+H\left(\mathrm{H}^{+}\right)-H(\mathrm{~A}-\mathrm{OH})
$$

where $\mathrm{H}\left(\mathrm{A}-\mathrm{O}^{-}\right)$is the enthalpy of $\mathrm{A}^{-} \mathrm{O}^{-}$. The anion on further on loses an electron:

$$
\mathrm{A}-\mathrm{O}^{-} \rightarrow \mathrm{A}-\mathrm{O}^{\bullet}+\mathrm{e}^{-}
$$

This step corresponds to electron transfer enthalpy (ETE) which can be calculated according to the following equation: 


$$
\mathrm{ETE}=H\left(\mathrm{~A}-\mathrm{O}^{\bullet}\right)+H\left(\mathrm{e}^{-}\right)-H\left(\mathrm{~A}^{-} \mathrm{O}^{-}\right)
$$

The values for the solvation enthalpies of the proton and electron were taken from literature (Foti et al. 2004; Marković et al. 2013).

This mechanism is particularly important for the explanation of the antioxidant activity of phenolic compounds (Foti 2007). Analysing the antioxidant activity two important chemical characteristics of the antioxidant should be mentioned. The first one is its pKa, which is responsible for the determination of the proportion of the deprotonated species in water solution and at each $\mathrm{pH}$ value, for instance at $\mathrm{pH}=7.4$ (physiological conditions). The second one is the electron donating ability of the deprotonated antioxidant. In this case the electron accepting ability of the free radical species should also be pointed out. Moreover, the role of the solvents in these reactions should also not be forgotten. The solvent should be polar and protic, and be able to provide good solvation of the anion formed. Therefore, it is expected that the SPLET mechanism is dominant in water but not in the lipid phase characteristic to the biological systems. SPLET has being identified as a crucial mechanism in the scavenging activity exerted by numerous compounds in polar environments. Some examples are curcumin (Litwinienko and Ingold 2004; Galano 2011) alizarin and alizarin red S (Jeremić et al. 2014), esculetin (Medina eta al. 2014), hydroxybenzoic and dihydroxybenzoic acids (Marković et al. 2014; PérezGonzález et al. 2014), resveratrol (Iuga et al 2012), morin (Marković et al. 2012a; Marković et al. 2012b), flavonoids, (Musialik et al. 2009), vitamin E (Musialik and Liteinenko 2005), quercetin (Marković et al., 2010; Marković et al., 2013) procyanidins (Mendoza-Wilson et al. 2014) kaempferol (Dimitrić-Marković et al. 2014), gallic acid (Djorović et al. 2014, Marino et al. 2014), baicalein (Marković et al. 2012) and purpurin (Jeremić et al. 2012).

\subsection{Sequential proton loss hydrogen atom transfer (SPLHAT) mechanism}

The first step of this mechanism is identical to that one of the SPLET Eq. 8, while the second one differs from SPLET. In this step the anion further loses a hydrogen atom:

$$
\mathrm{A}-(\mathrm{OH}) \mathrm{O}^{-} \rightarrow \mathrm{A}^{-} \mathrm{OO}^{-\bullet}+\mathrm{H}^{\bullet}
$$

This step corresponds to hydrogen atom transfer enthalpy (HATs) which can be calculated according to the following equation:

$$
\text { HATs }=H\left(\mathrm{~A}^{-} \mathrm{OO}^{-\bullet}\right)+H\left(\mathrm{H}^{\bullet}\right)-H\left(\mathrm{~A}-(\mathrm{OH}) \mathrm{O}^{-}\right)
$$

$H\left(\mathrm{~A}^{-} \mathrm{OO}^{-\bullet}\right)$ and $H\left(\mathrm{~A}^{-}(\mathrm{OH}) \mathrm{O}^{-}\right)$are the enthalpies of the radical anion and anion, respectively.

All investigated flavonoids are presented in Figure 2. On the basis of the mutual comparison of the thermodynamical parameters BDE, IP, and PA for these compounds it was found that that IP values are the largest, indicating the SET-PT mechanism is not the favourable reaction path for all investigated compounds, in all investigated solvents. On the other hand, HAT and PCET are dominant mechanisms of the antioxidative action in gaseous phase, for all the investigated compounds. Also, the HAT mechanism is predominant reaction pathway for baicalein (Marković et al. 2011), morin (Marković et al. 2012a), and morin 2'-Oanion (Marković et al. 2012b) in benzene as a nonpolar solvent. In polar solvents, like water, the SPLET mechanism is predominant reaction pathway for all compounds. It is obvious that the polarity of the solvent plays an important role in determining the dominant mechanistic pathway of the antioxidative action of the investigated compounds. The obtained results are expected, since that the first step of the SPLET mechanism is the formation of the corresponding anion, which is strongly solvated in an aqueous medium. On the other hand, free radicals are not solvated in the same way as ions. It is necessary for a solvent, having an unpaired electron to solvate free radicals. However, the interactions between free radicals are weak, because the solvents have all their electrons paired. Even more, water as a solvent 
increases molecular mobility and rates of reaction, reducing radical lifetimes. Also, water as proton donor increases the rates of radical quenching.

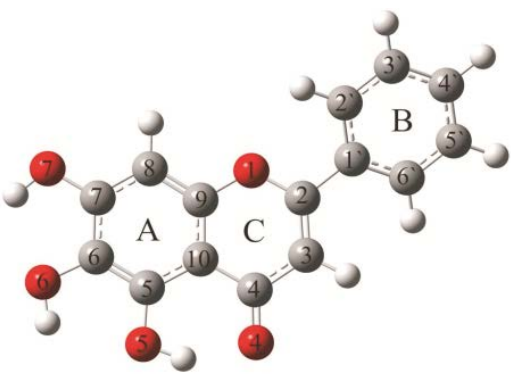

Baicalein

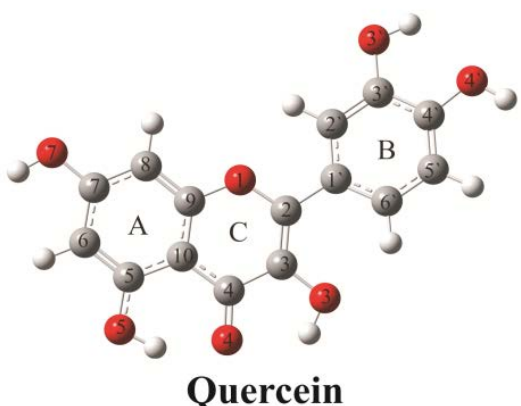

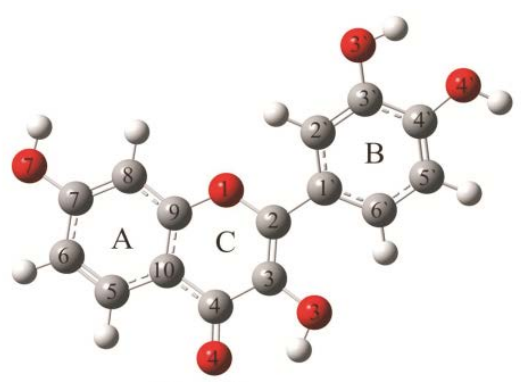

Fisetin

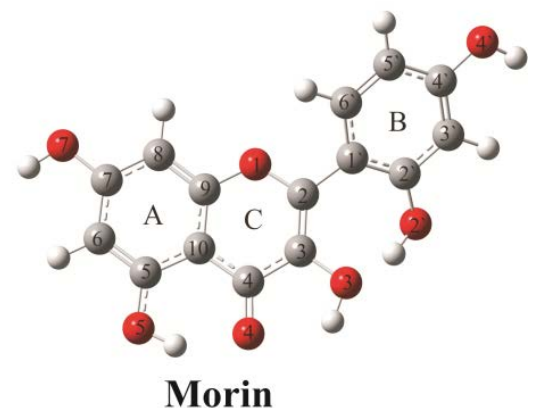

Fig. 2. The most stable structures of the investigated compounds

All investigated anthraquinones are presented in Figure 3. HAT is the most favoured radical scavenging mechanism of all three anthraquinones in the gaseous phase. (Jeremić et al. 2014; Jeremić et al. 2012) On the other hand, the SPLET mechanism is preferable mechanism in water. Our calculations showed that SET-PT is not probable reaction path for all three molecules in both gaseous and water phases.

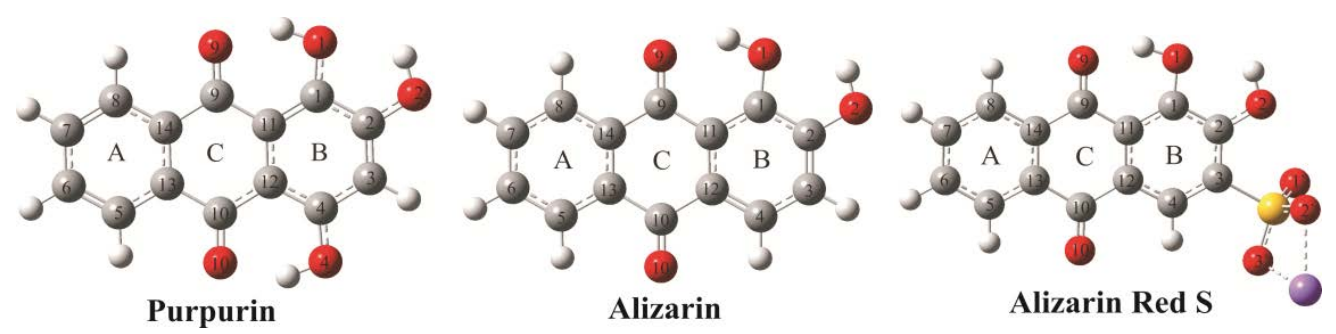

Fig. 3. The most stable structures of the investigated anthraquinones

The optimized structures of the investigated 1,2,4-triazole-3-thiones in methanol are presented in Figure 4. On the basis of the thermodynamic values: BDE, IP, PDE, PA, and ETE, one can assume which antioxidant mechanism will prevail under certain conditions. As expected the IP values are significantly higher than the corresponding BDE, and p PA values, for all examined compounds. This indicates that the SET-PT mechanism is not favourable reaction pathway for the investigated compounds. The PA values are significantly lower than the BDE values, suggests the SPLET as the dominant mechanism. The obtained thermodynamic 
values are in good agreement with the experimental $\mathrm{IC}_{50}$ values (Ivanović et al. 2016). The compounds $\mathbf{4 f}$ and $\mathbf{4 h}$ have the lowest $\mathrm{PA}$ and $\mathrm{IC}_{50}$ values. This result is not surprising, since the previous investigations of the antioxidant activity of Schiff bases showed that polar protic solvents, such as methanol and ethanol, favour the SPLET mechanistic pathway.

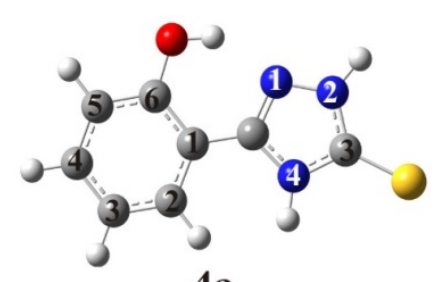

$4 \mathbf{a}$

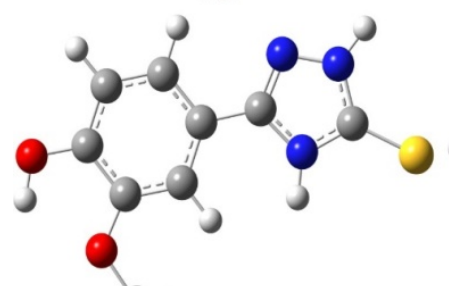

$4 d$

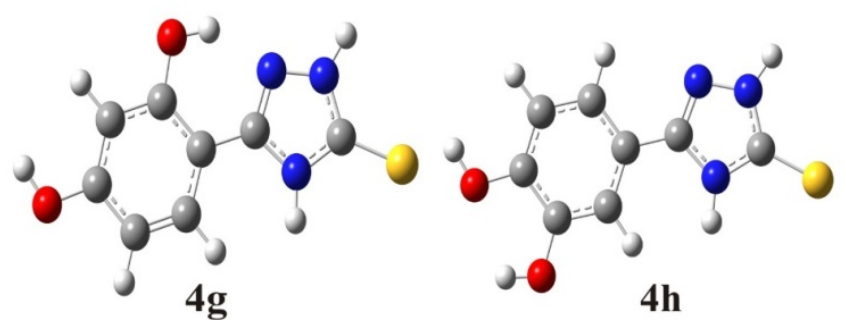

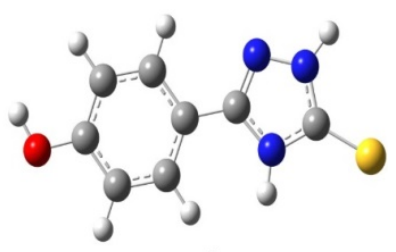

$4 c$

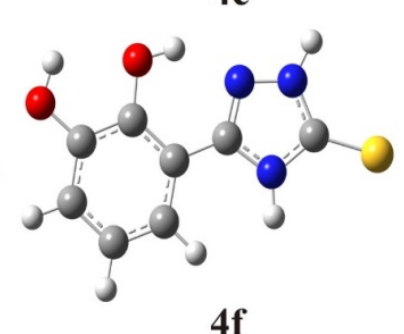

4f

Fig. 4. The most stable structures of the 1,2,4-triazole-3-thiones

\section{Antioxidative mechanisms employing different free radicals}

The scavenging mechanisms of different antioxidants are highly influenced by the properties of the scavenged radical species (Hussein 2011; Fang et al. 2013). The Reaction enthalpy and Gibbs energy are quantity that can successfully contribute to the understanding of these processes. A direct approach to estimate the $\Delta \boldsymbol{H}$ and $\Delta \boldsymbol{G}$ of a reaction is to apply the fundamental thermodynamic relationship, i.e., to subtract the enthalpy or free energy of the reactants from the enthalpy or free energy of the products. If the reaction is exothermic or exergonic, it means that the newly formed radical is more stable than the starting one, implying the reaction path as favourable. Otherwise, if the reaction is endothermic or endergonic, the reaction path is not favoured, because the newly formed radical is less stable than the starting one.

Since the above mentioned equations $1,4,6,8,10$ are not dependent upon the free radicals type it is necessary to examine the influence of the specific free radicals on possible antioxidative mechanism. To be able to examine the influence of specific free radicals to on antioxidative mechanism, the reactive particle $\mathrm{RO}^{\bullet}$ needs to be introduced. 
In the HAT mechanism, the hydrogen atom is transferred from antioxidant to the free radical $\mathrm{RO}^{\bullet}$ :

$$
\mathrm{A}-\mathrm{OH}+\mathrm{RO} \bullet \rightarrow \mathrm{A}-\mathrm{O}^{\bullet}+\mathrm{ROH}
$$

$\Delta \boldsymbol{H}_{\mathrm{BDE}}$ for the HAT mechanism can be calculated using the following equation:

$$
\Delta \boldsymbol{H}_{\mathrm{BDE}}=\boldsymbol{H}\left(\mathrm{AO}^{\bullet}\right)+\boldsymbol{H}(\mathrm{ROH})-\boldsymbol{H}(\mathrm{A}-\mathrm{OH})-\boldsymbol{H}\left(\mathrm{RO}^{\bullet}\right)
$$

where the $\boldsymbol{H}\left(\mathrm{AO}^{\bullet}\right), \boldsymbol{H}(\mathrm{ROH}), \boldsymbol{H}\left(\mathrm{A}^{-} \mathrm{OH}\right)$, and $\boldsymbol{H}\left(\mathrm{RO}^{\bullet}\right)$ are the enthalpies of the radical, molecule obtained after the hydrogen atom abstraction from the molecule of antioxidant, starting antioxidant, and the free radical species, respectively. Lower $\Delta H_{\mathrm{BDE}}$ values can be attributed to a greater ability of antioxidant to donate a hydrogen atom to $\mathrm{RO}{ }^{\bullet}$ species.

The first step in the SET-PT mechanism is transfer of an electron from the antioxidant to free radical species, yielding the corresponding radical cation $\mathrm{A}-\mathrm{OH}^{\bullet+}$ and anion.

$$
\mathrm{A}-\mathrm{OH}+\mathrm{RO}^{\bullet} \rightarrow \mathrm{A}^{-} \mathrm{OH}^{\bullet+}+\mathrm{RO}^{-}
$$

$\Delta \boldsymbol{H}_{\mathrm{IP}}$ for the first step of the SET-PT mechanism can be calculated as follows:

$$
\Delta \boldsymbol{H}_{\mathrm{IP}}=\boldsymbol{H}\left(\mathrm{A}^{-} \mathrm{OH}^{\bullet+}\right)+\boldsymbol{H}\left(\mathrm{RO}^{-}\right)-\boldsymbol{H}(\mathrm{A}-\mathrm{OH})-\boldsymbol{H}\left(\mathrm{RO}^{\bullet}\right)
$$

where the $\mathbf{H}\left(\mathrm{A}-\mathrm{OH}^{\bullet+}\right)$ and $\boldsymbol{H}\left(\mathrm{RO}^{-}\right)$are the enthalpies of the radical cation of the initial antioxidant and anion generated from the corresponding initial free radical.

The second step of this mechanism is deprotonation of $\mathrm{A}-\mathrm{OH}^{\bullet+}$ by $\mathrm{RO}^{-}$:

$$
\mathrm{A}^{-} \mathrm{OH}^{\bullet+}+\mathrm{RO}^{-} \rightarrow \mathrm{A}^{-} \mathrm{O}^{\bullet}+\mathrm{ROH}
$$

$\Delta \boldsymbol{H}_{\mathrm{PDE}}$ can be calculated using the following equation:

$$
\Delta \boldsymbol{H}_{\mathrm{PDE}}=\boldsymbol{H}\left(\mathrm{A}^{-} \mathrm{O}^{\bullet}\right)+\boldsymbol{H}(\mathrm{ROH})-\boldsymbol{H}\left(\mathrm{A}-\mathrm{OH}^{\bullet+}\right)-\boldsymbol{H}\left(\mathrm{RO}^{-}\right)
$$

The first step in the SPLET mechanism is deprotonation of antioxidant by $\mathrm{RO}^{-}$or other base. The outcome of this reaction is the formation of the anion $\mathrm{A}^{-} \mathrm{O}^{-}$:

$$
\mathrm{A}-\mathrm{OH}+\mathrm{RO}^{-} \rightarrow \mathrm{A}^{-} \mathrm{O}^{-}+\mathrm{ROH}
$$

$\Delta \boldsymbol{H}_{\mathrm{PA}}$ can be calculated as follows:

$$
\Delta \boldsymbol{H}_{\mathrm{PA}}=\boldsymbol{H}\left(\mathrm{A}^{-} \mathrm{O}^{-}\right)+\boldsymbol{H}(\mathrm{ROH})-\boldsymbol{H}(\mathrm{A}-\mathrm{OH})-\boldsymbol{H}\left(\mathrm{RO}^{-}\right)
$$

In the next step electron transfer from $\mathrm{A}^{-} \mathrm{O}^{-}$to $\mathrm{RO}^{\bullet}$ takes place:

$$
\mathrm{A}-\mathrm{O}^{-}+\mathrm{RO}^{\bullet} \rightarrow \mathrm{A}^{-} \mathrm{O}^{\bullet}+\mathrm{RO}^{-}
$$

$\Delta \boldsymbol{H}_{\mathrm{ETE}}$ can be determined by the equation:

$$
\Delta \boldsymbol{H}_{\mathrm{ETE}}=\boldsymbol{H}\left(\mathrm{A}^{-} \mathrm{O}^{\bullet}\right)+\boldsymbol{H}\left(\mathrm{RO}^{-}\right)-\boldsymbol{H}\left(\mathrm{A}^{-} \mathrm{O}^{-}\right)-\boldsymbol{H}\left(\mathrm{RO}^{\bullet}\right)
$$

The investigated antioxidants are presented in Figures 3 and 5. On the basis of mutual comparison of the thermodynamical parameters $\Delta \boldsymbol{H}_{\mathrm{BDE}}, \Delta \boldsymbol{H}_{\mathrm{IP}}$, and $\Delta \boldsymbol{H}_{\mathrm{PA}}$ for all the investigated antioxidants, it was found that that $\Delta \boldsymbol{H}_{\mathrm{IP}}$ values are the largest, clearly indicating SET-PT mechanism as not favourable reaction path for all investigated antioxidants and free radicals, in all solvents. This result is in accordance with the usual thermodynamic calculations previously described. 


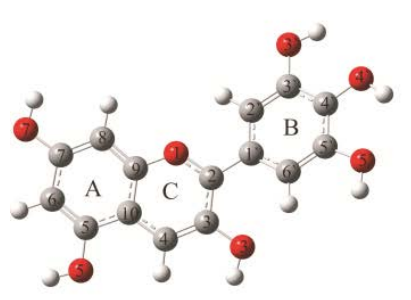

Delphinidin

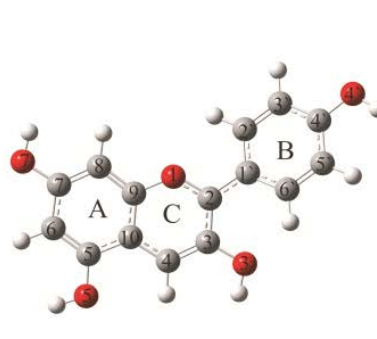

Pelargonidin

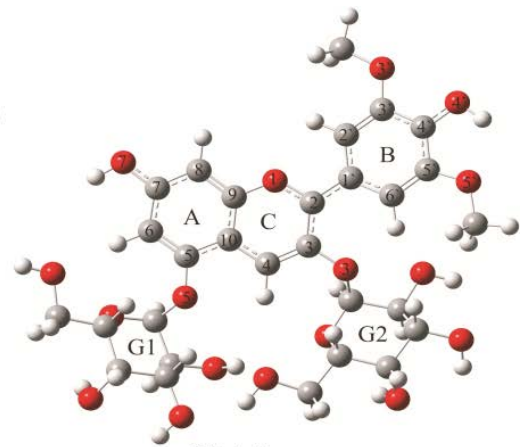

Malvin

Fig. 5. The most stable structures of the delphinidin, pelargonidin, and malvin

Study of the interaction between baicalein and ${ }^{\circ} \mathrm{OH}$ showed that there is a competition between HAT and SPLET mechanisms in all used polar solvents (water, ethanol, DMSO, and DMF) (Dimitrić-Marković et al. 2014). The same result was obtained for delphinidin, pelargonidin, malvin, and fisetin with the same radicals in the same solvents (Dimitric Marković et al. 2017) (Dimitrić Marković et al. 2014). The less reactive the ${ }^{\bullet} \mathrm{OOH}$ showed that SPLET mechanism is prevailing reaction path in all used polar solvents for baicalein and fisetin (Dimitrić-Marković et al. 2014) . On the basis of the thermodynamical values, it was found that The C4'-OH group of delphinidin was the most favoured site for homolytic (HAT) and heterolytic O-H (SPLET) breaking in protic and aprotic solvents. (Dimitrić Marković et al. 2017) The most reactive sites in pelargonidin are C3-OH (HAT) and C7-OH (SPLET), and in malvin C4'-OH (HAT) and C7-OH (SPLET) in all solvents considered (Dimitrić-Marković et al. 2014). The reaction enthalpies for fisetin and baicalein, with hydroxyl radicals, are exothermic in all solvent. The calculated energy values for the reactions of the investigated molecules and hydroxyl radicals point to HAT and SPLET as the operative radical scavenging mechanisms in all solvents under investigation. It should be also noted that the C4'-OH group of fisetin is the most favoured site for both mechanisms in all solvents (Dimitrić-Marković et al. 2017). On the other hand, the most reactive site in baicalein are the C6-OH (HAT) and C7-OH (SPLET) positions (Dimitrić-Marković et al. 2014).

In the reaction of quercetin radical cation with the MeS anion, in both gaseous and aqueous phases, an electron from a lone pair of the MeS anion spontaneously transfers to quercetin radical cation, yielding quercetin and $\mathrm{CH}_{3} \mathrm{~S}$ radical as reaction complex. It means that this reaction undergoes the HAT mechanism. On the other hand, in the case of reaction of quercetin radical cation with methylamine in both gaseous and aqueous phases obey the SET-PT mechanism is operative. Actually, quercetin radical cation spontaneously donates a proton to the methylamine. The reaction with the hydroxide anion lies in the middle of these two extremes. In the gaseous phase quercetin radical cation and the hydroxide anion spontaneously transform into Q and hydroxyl radical, which further conform to the HAT mechanism (Marković et al. 2013). Oppositely, quercetin radical cation can undergo the SET-PT mechanism in the presence of hydroxide anion in the aqueous solution. The main reason lies in the fact that the charged particles are additionally stabilized in polar solvents. Finally, we can concluded that whatever the source of quercetin radical cation is, this radical cation will spontaneously be transformed into quercetin in the presence of bases which HOMO energies are higher than the SOMO energy of quercetin radical cation in a given medium. It means that quercetin radical cation cannot undergo the SET-PT mechanism in such an environment. On the other hand, SET-PT is the plausible mechanism of quercetin radical cation in the presence of 
bases which HOMO energy is lower than the SOMO energy of quercetin radical cation in a given medium (Marković et al. 2013).

As regards to the antioxidant properties of Schiff bases (Figure 6) in the presence of ${ }^{\bullet} \mathrm{OH}$, - $\mathrm{OOH},\left(\mathrm{CH}_{2}=\mathrm{CH}-\mathrm{O}-\mathrm{O}^{*}\right)$, and ${ }^{-\bullet} \mathrm{O}_{2}$, it was found that SET-PT is not an operative antioxidant mechanism. As for radical scavenging of hydroxy radical, it was found that SPLET and PCET are competitive mechanisms in all solvents. On the other hand, ${ }^{\circ} \mathrm{OOH}$ and $\mathrm{CH}_{2}=\mathrm{CH}-\mathrm{O}-\mathrm{O}$ ', will react via SPLET mechanism in polar and nonpolar solvents. Finally it should be noted that these Schiff bases will react very slowly with the superoxide anion radical with s superoxide radical in nonpolar solvents very slowly, while these bases will not react with superoxide anion radical in nonpolar solvents.
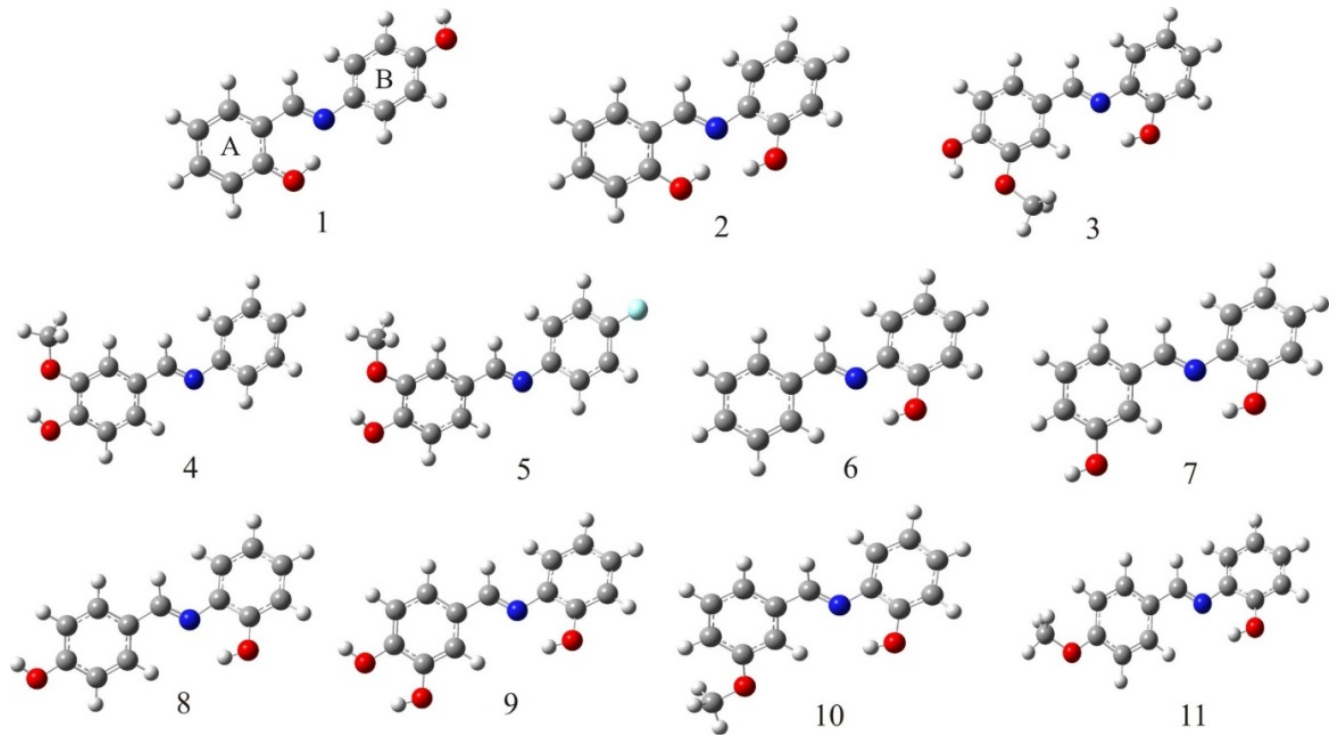

Fig. 6. The most stable structures of the Schiff bases

Acknowledgements The authors acknowledge support of the Ministry of Education, Science and Technological Development of Serbia, grants OI: 172015, 174028).

Извод

\section{Испитивање механизама антиоксидативног дејства различитих антиоксиданата}

\section{3. Марковић ${ }^{1,2}$}

${ }^{1}$ Департман за хемијско-технолошке науке, Државни универзитет у Новом Пазару, Вука Караџића бб, 36300 Нови Пазар, Србија

${ }^{2}$ Истраживачко-развојни центар за биоинжењеринг БиоИРЦ, Првослава Стојановића 6 , 34000 Крагујевац, Србија

имејл: zmarkovic@np.ac.rs 


\section{Резиме}

Антиоксиданти остварују своју активност помоћу неколико реакционих механизама: преносом атома водоника (НАТ), куплованим преносом протона и електрона (PCET), секвенцијалним губитком протона праћеним преносом електрона (SPLET), преносом једног електрона праћеним преносом протона (SET-PT), образовањем радикалског адукта и секвенцијалним губитком протона праћеним преласком атома водоника. Антиоксидативна активност различитих једињења (флавона, флавонола, и Шифових база) испитивана je TEAC (Trolox equivalent antioxidative capacity) тестом и методом електронске парамагнетне резонанције. Механизми антиоксидативне активности (НАТ, PCET, SPLET, и SET-PT) испитани су коришћењем следећих термодинамичких параметара: енталпија дисоцијације везе, јонизациони потенцијал, енталпија дисоцијације протона, афинитет протона и енталпија преноса електрона. Утицај различитих радикала је испитан применом одговарајућих изодезмичких реакција. Испитан је реакциони механизам и утицај радикала код НАТ механизма, и у другом кораку SET-PT механизма. Резултати ових истраживања доприносе расветљавању и разумевању сложених процеса антиоксидативне активности.

Кључне речи: DFT, антиоксиданти, HAT, PCET, SPLET

\section{References}

Álvarez-Diduk R, Galano A (2015). Adrenaline and Noradrenaline: Protectors against Oxidative Stress or Molecular Targets? J. Phys. Chem. B., 119, 3479-3491.

Ames BN, Shigenaga MK, Hagen TM (1993). Oxidants, antioxidants, and the degenerative diseases of aging. Proc. Natl. Acad. Sci. U. S. A., 90, 7915-7922.

Anouar EH, Raweh S, Bayach I, Taha M, Baharudin MS, Di Meo F, Hasan MH, Adam A, Ismail NH, Weber JF, Trouillas P (2013). Antioxidant properties of phenolic Schiff bases: structure-activity relationship and mechanism of action. J. Comput. Aided. Mol. Des., 27, 951-964.

Barber SC, Mead RJ, Shaw PJ (2006). Oxidative stress in ALS: A mechanism of neurodegeneration and a therapeutic target. Biochim. Biophys. Acta - Mol. Basis Dis., 1762, 1051-1067.

Barnham KJ, Masters CL, Bush AI (2004). Neurodegenerative diseases and oxidative stress. Nat. Rev. Drug Discov., 3, 205-214.

Cheng L-X, Tang J-J, Luo H, Jin X-L, Dai F, et al. 2010. Antioxidant and antiproliferative activities of hydroxyl-substituted Schiff bases. Bioorg. Med. Chem. Lett., 20, 2417-2420.

Dhiman SB, Kamat JP, Naik DB (2009). Antioxidant activity and free radical scavenging reactions of hydroxybenzyl alcohols. Biochemical and pulse radiolysis studies. Chem. Biol. Interact., 182, 119-127.

Di Meo F, Lemaur V, Cornil J, Lazzaroni R, Duroux J-L, Olivier Y, Trouillas P (2013). Free Radical Scavenging by Natural Polyphenols: Atom versus Electron Transfer. J. Phys. Chem. A., 117, 2082-2092.

Dimitrić Marković JM, Milenković D, Amić D, Popović-Bijelić A, Mojović M, Pašti IA, Marković ZS (2014). Energy requirements of the reactions of kaempferol and selected radical species in different media: towards the prediction of the possible radical scavenging mechanisms. Struct. Chem., 25, 1795-1804. 
Dimitrić Marković JM, Milenković D, Amić D, Mojović M, Pašti I, Marković ZS (2014). The preferred radical scavenging mechanisms of fisetin and baicalein towards oxygen-centred radicals in polar protic and polar aprotic solvents. RSC Adv., 4, 32228-32236.

Dimitrić Marković JM, Pejin B, Milenković D, Amić D, Begović N, Mojović M (2017). Antiradical activity of delphinidin, pelargonidin and malvin towards hydroxyl and nitric oxide radicals: The energy requirements calculations as a prediction of the possible antiradical mechanisms. Food Chem., 218,440-446.

Ezabadi IR, Camoutsis C, Zoumpoulakis P, Geronikaki A, Soković M, Glamocilija J, Cirić A (2008). Sulfonamide-1,2,4-triazole derivatives as antifungal and antibacterial agents: Synthesis, biological evaluation, lipophilicity, and conformational studies. Bioorg. Med. Chem., 16, 1150-1161.

Đorović J, Marković JMD, Stepanić V, Begović N, Amić D, Marković Z (2014). Influence of different free radicals on scavenging potency of gallic acid. J. Mol. Model., 20, 2345.

Fang Y-Z, Yang S, Wu G (2002). Free radicals, antioxidants, and nutrition. Nutrition., 18, 872879.

Foti MC (2007). Antioxidant properties of phenols. J. Pharm. Pharmacol., 59, 1673-85.

Foti MC, Daquino C, Geraci C (2004). Electron-Transfer Reaction of Cinnamic Acids and Their Methyl Esters with the DPPH• Radical in Alcoholic Solutions. J Org Chem., 69, 2309-2314.

Galano A (2011). On the direct scavenging activity of melatonin towards hydroxyl and a series of peroxyl radicals. Phys. Chem. Chem. Phys., 13, 7178-7188.

Galano A (2015). Free Radicals Induced Oxidative Stress at a Molecular Level: The Current Status, Challenges and Perspectives of Computational Chemistry Based Protocols. J. Mex. Chem. Soc., 59, 231-262.

Galano A, Alvarez-Idaboy JR. 2013. A computational methodology for accurate predictions of rate constants in solution: Application to the assessment of primary antioxidant activity. $J$. Comput. Chem., 34, 2430-2445.

Galano A, Alvarez-Idaboy JR (2009). Guanosine + OH Radical Reaction in Aqueous Solution: A Reinterpretation of the UV-vis Data Based on Thermodynamic and Kinetic Calculations. Org. Lett., 11, 5114-5117.

Galano A, Mazzone G, Alvarez-Diduk R, Marino T, Alvarez-Idaboy JR, Russo N (2016). Food Antioxidants: Chemical Insights at the Molecular Level. Annu. Rev. Food Sci. Technol., 7, 335-352.

Galano A, Tan DX, Reiter RJ (2013). On the free radical scavenging activities of melatonin's metabolites, AFMK and AMK. J. Pineal Res., 54, 245-257.

Galano A, Tan DX, Reiter RJ (2014). Cyclic 3-hydroxymelatonin, a key metabolite enhancing the peroxyl radical scavenging activity of melatonin. RSC Adv., 4, 5220-5227.

Hodnett EM, Dunn WJ (1970). Structure-antitumor activity correlation of some Schiff bases. J. Med. Chem., 13, 768-770.

Hussein MA (2011). A Convenient Mechanism for the Free Radical Scavenging Activity of Resveratrol. Int. J. Phytomedicine., 3, 459-469.

Iuga C, Alvarez-Idaboy JR, Russo N (2012). Antioxidant Activity of trans -Resveratrol toward Hydroxyl and Hydroperoxyl Radicals: A Quantum Chemical and Computational Kinetics Study. J. Org. Chem., 77, 3868-3877.

Ivanović N, Jovanović L, Marković Z, Marković V, Joksović MD,Milenković D, Đurđević PT, Ćirić A,Joksović LJ (2016). Potent 1,2,4-Triazole-3-thione Radical Scavengers Derived from Phenolic Acids: Synthesis, Electrochemistry, and Theoretical Study. ChemistrySelect., 1,3870-3878.

Jeremić S, Filipović N, Peulić A, Marković Z (2014). Thermodynamical aspect of radical scavenging activity of alizarin and alizarin red S. Theoretical comparative study. Comput. Theor. Chem., 1047, 15-21. 
Jeremić SR, Šehović SF, Manojlović NT, Marković ZS (2012). Antioxidant and free radical scavenging activity of purpurin. Monatshefte für Chemie - Chem. Mon., 143, 427-435.

Joshi R, Gangabhagirathi R, Venu S, Adhikari S, Mukherjee T (2012). Antioxidant activity and free radical scavenging reactions of gentisic acid: in-vitro and pulse radiolysis studies. Free Radic. Res., 46, 11-20.

Kane JM, Dudley MW, Sorensen SM, Miller FP (1988). 2,4-Dihydro-3H-1,2,4-triazole-3thiones as potential antidepressant agents. J. Med. Chem., 31, 1253-1258.

Khan KM, Taha M, Naz F, Siddiqui S, Ali S, Rahim F, Perveen S, Choudhary MI (2012). Acylhydrazide Schiff bases: DPPH radical and superoxide anion scavengers. Med. Chem., 8, 705-710.

Khan KM, Shah Z, Uddin Ahmad V, Khan M, Taha M, Rahim F, Ali S, Ambreen N, Perveen S, Choudhary MI, Voelter W (2012). 2,4,6-Trichlorophenylhydrazine Schiff Bases as DPPH Radical and Super Oxide Anion Scavengers. Med Chem., 8,452-461.

Khiati Z, Othman AA, Sanchez-Moreno M, Bernard M-C, Joiret S,Sutter EMM, Vivier V (2011). Corrosion inhibition of copper in neutral chloride media by a novel derivative of 1,2,4-triazole. Corros. Sci., 53, 3092-3099.

Klein E, Lukeš V, Ilčin M (2007). DFT/B3LYP study of tocopherols and chromans antioxidant action energetics. Chem. Phys., 336, 51-57.

Khan KM, Taha M, Naz F, Siddiqui S, Ali S, Rahim F, Perveen S, Choudhary MI (2012). Acylhydrazide Schiff bases: DPPH radical and superoxide anion scavengers. Med. Chem., 8, 705-710.

Khan KM, Shah Z, Uddin Ahmad V, Khan M, Taha M, Rahim F, Ali S, Ambreen N, Perveen S, Choudhary MI, Voelter W (2012). 2,4,6-Trichlorophenylhydrazine Schiff Bases as DPPH Radical and Super Oxide Anion Scavengers. Med Chem., 8,452-461.

Khiati Z, Othman AA, Sanchez-Moreno M, Bernard M-C, Joiret S,Sutter EMM, Vivier V (2011). Corrosion inhibition of copper in neutral chloride media by a novel derivative of 1,2,4-triazole. Corros. Sci., 53, 3092-3099.

León-Carmona JR, Galano A (2011). Is caffeine a good scavenger of oxygenated free radicals? J. Phys. Chem. B., 115, 4538-4546.

Litwinienko G, Ingold KU (2004). Abnormal Solvent Effects on Hydrogen Atom Abstraction. 2. Resolution of the Curcumin Antioxidant Controversy. The Role of Sequential Proton Loss Electron Transfer. J Org Chem., 69, 5888-5896.

Litwinienko G, Ingold KU (2005). Abnormal Solvent Effects on Hydrogen Atom Abstraction. 3. Novel Kinetics in Sequential Proton Loss Electron Transfer Chemistry. J. Org. Chem., 70, 8982-8990.

Litwinienko G, Ingold KU (2007). Solvent Effects on the Rates and Mechanisms of Reaction of Phenols with Free Radicals. Acc. Chem. Res., 40, 222-230.

Litwinienko G, Ingold KU (2003). Abnormal Solvent Effects on Hydrogen Atom Abstractions. 1. The Reactions of Phenols with 2,2-Diphenyl-1-picrylhydrazyl (dpph•) in Alcohols. $J$ Org Chem., 68, 3433-3438.

Lleó A, Greenberg SM, Growdon JH (2006). Current Pharmacotherapy for Alzheimer's Disease. Annu. Rev. Med., 57,513-33.

Lozier RH, Bogomolni RA, Stoeckenius W (1975). Bacteriorhodopsin: a light-driven proton pump in Halobacterium Halobium. Biophys. J., 15, 955-962.

Marino T, Galano A, Russo N (2014). Radical Scavenging Ability of Gallic Acid toward OH and $\mathrm{OOH}$ Radicals. Reaction Mechanism and Rate Constants from the Density Functional Theory. J. Phys. Chem. B., 118, 10380-10389.

Marković Z, Amić D, Milenković D, Dimitrić-Marković JM, Marković S (2013). Examination of the chemical behavior of the quercetin radical cation towards some bases. Phys. Chem. Chem. Phys., 15, 7370-7378. 
Marković Z, Đorović J, Dimitrić Marković JM, Živić M, Amić D (2014). Investigation of the radical scavenging potency of hydroxybenzoic acids and their carboxylate anions. Monatshefte für Chemie - Chem. Mon., 145, 953-962

Marković Z, Milenković D, Đorović J, Dimitrić Marković JM, Stepanić V, Lučić B, Amić D (2012a). PM6 and DFT study of free radical scavenging activity of morin. Food Chem., 134,1754-1760.

Marković Z, Milenković D, Đorović J, Dimitrić Marković JM, Stepanić V, Lučić B, Amić D (2012b). Free radical scavenging activity of morin 2'-O- phenoxide anion. Food Chem., 135, 2070-2077.

Marković Z, Milenković D, Đorović J, Jeremić S (2013). Solvation enthalpies of the proton and electron in polar and non-polar solvents. J. Serbian Soc. Comput. Mech., 7, 1-9.

Marković ZS, Dimitrić Marković JM, Doličanin ĆB (2010). Mechanistic pathways for the reaction of quercetin with hydroperoxy radical. Theor. Chem. Acc., 127,69-80

Marković ZS, Dimitrić Marković JM, Milenković D, Filipović N (2011). Mechanistic study of the structure-activity relationship for the free radical scavenging activity of baicalein. $J$. Mol. Model., 17, 2575-2584.

Marković ZS, Marković S, Dimitrić Marković JM, Milenković D (2012c). Structure and reactivity of baicalein radical cation. Int. J. Quantum Chem. 112, 2009-2017.

Marković ZS, Dimitrić Marković JM, Doličanin ĆB (2010). Mechanistic pathways for the reaction of quercetin with hydroperoxy radical. Theor. Chem. Acc., 127, 69-80.

Mavrova AT, Wesselinova D, Tsenov YA, Denkova P (2009). Synthesis, cytotoxicity and effects of some 1,2,4-triazole and 1,3,4-thiadiazole derivatives on immunocompetent cells. Eur. J. Med. Chem., 44, 63-69.

Mazzone G, Galano A, Alvarez-Idaboy JR, Russo N (2016). Coumarin-Chalcone Hybrids as Peroxyl Radical Scavengers: Kinetics and Mechanisms. J. Chem. Inf. Model., 56, 662-670.

Medina ME, Galano A, Alvarez-Idaboy JR (2014). Theoretical study on the peroxyl radicals scavenging activity of esculetin and its regeneration in aqueous solution. Phys. Chem. Chem. Phys., 16, 1197-1207.

Mendoza-Wilson AM, Castro-Arredondo SI, Balandrán-Quintana RR (2014). Computational study of the structure-free radical scavenging relationship of procyanidins. Food Chem., 161,155-161.

Min DB, Boff JM (2002). Chemistry and Reaction of Singlet Oxygen in Foods. Compr. Rev. Food Sci. Food Saf., 1, 58-72.

Moosmann B, Behl C (2002). Antioxidants as treatment for neurodegenerative disorders. Expert Opin. Investig. Drugs., 11,1407-1435.

Musialik M, Kuzmicz R, Pawłowski TS, Litwinienko G (2009). Acidity of Hydroxyl Groups: An Overlooked Influence on Antiradical Properties of Flavonoids. J. Org. Chem., 74, 2699-2709.

Musialik M, Litwinienko G (2005). Scavenging of dpph` Radicals by Vitamin E Is Accelerated by Its Partial Ionization: the Role of Sequential Proton Loss Electron Transfer. Org. Lett., 2005, 7, 4951-4954.

Ozaslan M, Karagoz ID, Kilic IH, Guldur ME (2011). Ehrlich ascites carcinoma. African J. Biotechnol., 10, 2375-2378.

Palaska E, Şahin G, Kelicen P, Durlu NT, Altinok G (2002). Synthesis and anti-inflammatory activity of 1-acylthiosemicarbazides, 1,3,4-oxadiazoles, 1,3,4-thiadiazoles and 1,2,4triazole-3-thiones. Farm., 57, 101-107.

Parker JE, Warrilow AGS, Cools HJ, Martel CM, Nes WD, Fraaije BA, Lucas JA, Kelly DE, Kelly SL (2011). Mechanism of binding of prothioconazole to Mycosphaerella graminicola CYP51 differs from that of other azole antifungals. Appl. Environ. Microbiol., 77, 14601465. 
Plech T, Kaproń B, Łuszczki JJ, Paneth A, Siwek A, Kołaczkowski M, Żołnierek M, Nowak G (2014). Studies on the anticonvulsant activity of 4-alkyl-1,2,4-triazole-3-thiones and their effect on GABAergic system. Eur. J. Med. Chem., 86,690-699.

Radecka-Paryzek W, Pospieszna-Markiewicz I, Kubicki M (2007). Self-assembled twodimensional salicylaldimine lanthanum(III) nitrate coordination polymer. Inorganica Chim. Acta., 360, 488-496.

Rose RC, Bode AM (1993). Biology of free radical scavengers: an evaluation of ascorbate. FASEB J., 7, 1135-1142.

Sayre LM, Perry G, Smith MA (2008). Oxidative Stress and Neurotoxicity. Chem. Res. Toxicol., 21, 172-188.

Taha M, Ismail N, Jamil W, Yousuf S, Jaafar F, Ali MI, Kashif SM, Hussain E (2013). Synthesis, Evaluation of Antioxidant Activity and Crystal Structure of 2,4Dimethylbenzoylhydrazones. Molecules., 18,10912-10929.

Tamba M, Torreggiani A (1999). Hydroxyl radical scavenging by carnosine and $\mathrm{Cu}(\mathrm{II})-$ carnosine complexes: a pulse-radiolysis and spectroscopic study. Int. J. Radiat. Biol., 75, 1177-1188.

Troadec J-D, Marien M, Darios F, Hartmann A, Ruberg M, Colpaert F, Michel PP (2008). Noradrenaline provides long-term protection to dopaminergic neurons by reducing oxidative stress. J. Neurochem., 7,200-210. 